\title{
BULLETIN OF NEW ZEALAND SOCIETY FOR EARTHQUAKE ENGINEERING
}

\section{3-YEAR INDEX \\ 1996-1998}

\section{Key to Bulletin Issues:}

$\begin{array}{lll}\text { Vol. } & \text { 29, No.1 } & \text { March } \\ 29(2) & \text { June } \\ 29(3) & \text { September } \\ 29(4) & \text { December } \\ & \\ 30(1) & \text { March } \\ 30(2) & \text { June } \\ 30(3) & \text { September } \\ 30(4) & \text { December } \\ & \\ 31(1) & \text { March } \\ 31(2) & \text { June } \\ 31(3) & \text { September } \\ 31(4) & \text { December }\end{array}$

\section{AUTHOR INDEX}

A.

Andrews, A.L. Discussion - The seismic resistance of unreinforced masonry cantilever walls in low seismicity areas, by N.T.K. Lam, J.L. Wilson and G.L. Hutchinson, 28(3) pp 179-195. 29(1) 57

Ansell, J. see Reyners, M.

$30(3)$

Awata, Y. see Van Dissen, R.

29(3)

B.

Begg, J. see Van Dissen, R.

Benites, R. see Robinson, R.

Berrill, J.B. A note on the Hanmer Springs earthquake, Thursday 29/08/1996. 29(3) 208

Berrill, J.B. see Davis, R.O. 29(2)

Berrill, J.B. see Davis, R.O. 31(1)

Berryman, K.R. see Dowrick, D.J. 31(1)

Bolt, B.A. Intraplate seismicity and zonation. $\quad 29(4) 221$

Britton, N.R. see Brunsdon, D.R.

Brunsdon, D.R. Letter - re Earthquake risk (prone) buildings the Gisborne experience, by J.D.Wells, 29(3), September 1996.

29(4) 285
Brunsdon, D.R. Lifelines engineering - a long way in a decade. 30(2) 194

Brunsdon, D.R.: Britton, N.R.: Carter, R.J.: Crimp, R.F.: Gates, E.F.:Gordon, M.A.: Hughson, G.J.: Lamb, A.J.W.: Leslie, P.D.: Wabnitz, G.: Watson, A.C. Lessons for New Zealand lifelines organisations from the 17 January 1995 Great Hanshin Earthquake. 29(1) 1

Brunsdon, D.R.: Charleson, A.W.: King, A.B.: Middleton, D.A.: Sharpe, R.D.: Shephard, R.B.: Smith, E.G.C. Post@earthquake co-ordination of technical resources: the need for a unified approach.

29(4) 280

Brunsdon, D.R.: Shephard, R.B. Post-earthquake response: issues associated with compiling a register of engineers.

31(4) 281

Butcher, G.W. New Zealand National Society for Earthquake Engineering earthquake reconnaissance scheme.

29(2) 119

C.

Carter, R.J. see Brunsdon, D.R.

29(1)

Charleson, A.W. Seismic design within architectural education.

$30(1) 46$

Charleson, A.W. see Brunsdon, D.R.

Crimp, R.F. see Brunsdon, D.R.

D.

Davis, R.O.: Berrill, J.B. Energy dissipation and liquefaction at Port Island, Kobe.

31(1) 33

Davis, R.O.: Berrill, J.B. Liquefaction susceptibility based on dissipated energy: a consistent design methodology.

29(2) 83

Downes, G. see Grapes, R.

Dowrick, D.J. Damage and intensities in the magnitude 7.8 1931 Hawke's Bay, New Zealand, earthquake.

31(3) 139

Dowrick, D.J. The modified Mercalli earthquake intensity scale - revisions arising from recent studies of New Zealand earthquakes.

29(2) 92

Dowrick, D.J. see Zhao, J.X.

Dowrick, D.J.: Berryman, K.R.: McVerry, G.H.: Zhao, J.X. Earthquake hazard in Christchurch. $\quad 31(1) 1$ 
Dowrick, D.J.: Rhoades, D.A. Magnitudes of New Zealand earthquakes, 1901-1993.

31(4) 260

Dowrick, D.J.: Rhoades, D.A. Vulnerability of different classes of low-rise buildings in the 1987 Edgecumbe, New Zealand, earthquake.

30(3) 227

F.

Ferris, B. see Reyners, M.

G.

Gannon, C.R. see Monti, M.D.

Gates, E.F. see Brunsdon, D.R.

Gordon, M.A. see Brunsdon, D.R.

Grapes, R.: Downes, G. The 1855 Wairarapa, New Zealand, earthquake - analysis of historical data. $30(4) 271$

Gregory, G. Counting the cost: the economic effects of a major earthquake.

31(4) 288

Gregory, G. Natural disaster: finding, managing and sharing people and information.

31(2) 122

H.

Haines, A.J.: Yu, J. Observation and synthesis of spatiallyincoherent weak-motion wavefields at Alfredton basin, New Zealand.

30(1) 14

Hare, H.J. Case study: Christchurch Government Buildings strengthening and refurbishment.

29(3) 141

Harte, D. see Vere-Jones, D.

Holmes, W.T. Recent developments in earthquake hazard mitigation in the United States.

29(2) 107

Hopkins, D.C. NZNSEE 1997 Conference feature session on last decade report by session chairman. $30(2) 159$

Hughson, G.J. see Brunsdon, D.R.

29(1)

I.

Ingham, J.M.: Priestley, M.J.N.: Seible, F. Seismic response of bridge knee joints having columns with interlocking spirals.

30(2) 114

$\mathbf{J}$.

Jury, M.D. A decade of progress since the Edgecumbe earthquake - buildings.

$30(2) 174$

K.

King, A.B. NZNSEE President's page.

King, A.B. The fundamentals of an earthquake standard.

King, A.B. see Brunsdon, D.R.

Kowalsky, M.J. see Priestley, M.J.N.
Kozuch, M.J. see Vere-Jones, D.

$31(3)$

Krawinkler, H. Earthquake design and performance of steel structures.

29(4) 229

L.

Lamb, A.J.W. see Brunsdon, D.R.

Larkin, T.J. see Marks, S.

Leslie, P.D. see Brunsdon, D.R.

Liu, A.: Park, R. Seismic load tests on two concrete interior beam-column joints reinforced by plain round bars designed to pre-1970s codes.

31(3) 164

M.

Marks, S.: Larkin, T.J.: Pender, M.J. The dynamic properties of a pumiceous sand.

31(2) 86

McGinty, P. see Reyners, M.

McManus, K.J. Geotechnical earthquake engineering in New Zealand summary of ongoing research. 29(2) 128

McManus, K.J. US-Japan workshop on geotechnical aspects of recent earthquakes.

29(2) 124

McVerry, G.H. see Dowrick, D.J.

McVerry, G.H. see Zhao, J.X.

Megget, L.M. The seismic behaviour of small reinforced concrete beam-column knee joints. $\quad 31(4) 215$

Middleton, D.A. see Brunsdon, D.R.

Monti, M.D.: Zhao, J.X.: Gannon, C.R.: Robinson, W.H. Experimental results and dynamic parameters for the Penguin Vibration Damper (PVD) for wind and earthquake loading.

31(3) 177

Moss, P.J. 11th World Conference on Earthquake Engineering - Acapulco, Mexico, June 1996. 30(1) 51

Moss, P.J. Editorial.

29(1) Unpaged

Moss, P.J. Editorial.

29(3) Unpaged

Moss, P.J. Editorial.

29(4) Unpaged

N.

NZNSEE Study Group on post-earthquake building safety evaluation procedures. Post-earthquake building safety evaluation procedures Preparedness checklist and response plan for territorial authorities.

31(2) 103

Page, A.W. Unreinforced masonry structures - an Australian overview.

29(4) 242

Park, R. A static force-based procedure for the seismic assessment of existing reinforced concrete moment resisting frames.

30(3) 213

Park, R. An analysis of the failure of the columns of a 600 metre length of the Hanshin elevated expressway during the Great Hanshin Earthquake of 17 January 1995.

29(2) 73 
Park, R. Developments in seismic design procedures for bridges in New Zealand.

30(2) 177

Park, R. World Conferences on Earthquake Engineering (WCEE) Arrangements for 12WCEE in New $\begin{array}{ll}\text { Zealand. } & 31(2) 128\end{array}$

Park, R. see Liu, A.

Paulay, T. A review of code provisions for torsional seismic effects in buildings.

30(3) 252

Paulay, T. Seismic design for torsional response of ductile buildings.

29(3) 178

Pender, M.J. Earthquake resistant design of foundations.

29(3) 155

Pender, M.J. Recent developments in earthquake geotechnical engineering. 30(2) 167

Pender, M.J. see Marks, S.

Priestley, M.J.N. Brief comments on elastic flexibility of reinforced concrete frames and significance to seismic design.

31(4) 246

Priestley, M.J.N. Displacement-based seismic assessment of existing reinforced concrete buildings. 29(4) 256

Priestley, M.J.N. see Ingham, J.M.

Priestley, M.J.N.: Kowalsky, M.J. Aspects of drift and ductility capacity of rectangular cantilever structural walls.

31(2) 73

Q.

Quadri, N.D. The City of Los Angeles experience during the 1994 Northridge earthquake: managing resources and information.

30(1) 2

R.

Reyners, M.: McGinty, P.: Ansell, J.: Ferris, B. The Tikokino earthquake of 11 April 1993: movement at the plate interface in southern Hawkes Bay.

30(3) 242

Rhoades, D.A. see Dowrick, D.J.

Rhoades, D.A. see Dowrick, D.J.

$31(4)$

Robertson, T.W. The strengthening of Auckland Town Hall.

29(4) 273

Robinson, R.: Benites, R.: Van Dissen, R. Evidence for temporal clustering of large earthquakes in the Wellington region from computer models of seismicity.

$31(1) 24$

Robinson, W.H. see Monti, M.D.

$31(3)$

S.

Seible, F. see Ingham, J.M.

Sharpe, R.D. see Brunsdon, D.R.

Shephard, R.B. A decade of progress since the Edgecumbe earthquake: risk and insurance.
Shephard, R.B. see Brunsdon, D.R.

Shephard, R.B. see Brunsdon, D.R.

Shephard, R.B.: Smith, E.G.C.: Spurr, D.D. Earthquake insurance loss assessments for regions of Australia.

$30(1) 32$

Smith, E.G.C. A decade of progress in seismology since the Edgecumbe earthquake 30(2) 163

Smith, E.G.C. see Brunsdon, D.R.

Smith, E.G.C. see Shephard, R.B.

Spurr, D.D. see Shephard, R.B.

V.

Van Dissen, R. see Robinson, R.

Van Dissen, R.: Begg, J.: Awata, Y. Preliminary paleoearthquake investigations of active faults on Awaji Island, Japan, in relation to the 1995 Great Hanshin (Kobe) Earthquake.

29(3) 172

Vere-Jones, D.: Harte, D.: Kozuch, M.J. Operational requirements for an earthquake forecasting programme for New Zealand.

31(3) 194

W.

Wabnitz, G. see Brunsdon, D.R.

Walker, G.R. Prediction of insurance loss from earthquakes.

Watson, A.C. see Brunsdon, D.R.

29(1)

Webb, T.H. Principal earthquakes in New Zealand in 1995.

29(1) 56

Webb, T.H. Principal earthquakes in New Zealand in 1996.

30(1) 1

Wells, J.D. Earthquake risk (prone) buildings - the Gisborne experience.

29(3) 147

Y.

Yu, J. see Haines, A.J.

Z.

Zhao, J.X. The estimation of structural modal parameters from the responses of the Gisborne Post Office building in recent earthquakes.

31(1) 51

Zhao, J.X. see Dowrick, D.J.

Zhao, J.X. see Monti, M.D.

Zhao, J.X.: Dowrick, D.J.: McVerry, G.H. Attenuation of peak ground accelerations in New Zealand earthquakes.

30(2) 133 


\section{SUBJECT INDEX}

Base isolation - see Earthquake engineering

\section{Book reviews}

29(1) 59

Bridges (includes Roading)

An analysis of the failure of the columns of a 600 metre length of the Hanshin elevated expressway during the Great Hanshin Earthquake of 17 January 1995. Park, R.

29(2) 73

Developments in seismic design procedures for bridges in New Zealand. Park, R.

30(2) 177

Seismic response of bridge knee joints having columns with interlocking spirals. Ingham, J.M.: Priestley, M.J.N.: Seible, F.

30(2) 114

\section{Buildings}

A decade of progress since the Edgecumbe earthquake buildings. Jury, M.D. (And see Earthquake engineering.) 30(2) 174

A review of code provisions for torsional seismic effects in buildings. Paulay, T.

30(3) 252

Case study: Christchurch Government Buildings strengthening and refurbishment. Hare, H.J.

29(3) 141

Displacement-based seismic assessment of existing reinforced concrete buildings. Priestley, M.J.N.

29(4) 256

Seismic design for torsional response of ductile buildings. Paulay, T.

29(3) 178

The estimation of structural modal parameters from the responses of the Gisborne Post Office building in recent earthquakes. Zhao, J.X.

31(1) 51

The strengthening of Auckland Town Hall. Robertson, T.W

29(4) 273
Vulnerability of different classes of low-rise buildings in the 1987 Edgecumbe, New Zealand, earthquake. Dowrick, D.J.: Rhoades, D.A. $30(3) 227$

\section{Civil defence}

Operational requirements for an earthquake forecasting programme for New Zealand. Vere-Jones, D.: Harte, D.: Kozuch, M.J.

31(3) 194

Post-earthquake co-ordination of technical resources: the need for a unified approach. Brunsdon, D.R.: Charleson, A.W.: King, A.B.: Middleton, D.A.: Sharpe, R.D.: Shephard, R.B.: Smith, E.G.C.

29(4) 280

Short note - Emergency Services Review.

29(4) 284

The City of Los Angeles experience during the 1994 Northridge earthquake: managing resources and information. Quadri, N.D.

$30(1) 2$

Codes see Standards

\section{Conferences and seminars}

11th World Conference on Earthquake Engineering - Acapulco, Mexico, June 1996. Moss, P.J.

$30(1) 51$

Counting the cost: the economic effects of a major earthquake. Gregory, G.

31(4) 288

Natural disaster: finding, managing and sharing people and information. Gregory, G.

31(2) 122

NZNSEE 1997 Conference feature session on last decade report by session chairman. Hopkins, D.C. (And see Earthquake engineering.)

30(2) 159

US-Japan workshop on geotechnical aspects of recent earthquakes. McManus, K.J. 29(2) 124

World Conferences on Earthquake Engineering (WCEE) Arrangements for 12WCEE in New Zealand. Park, R.

31(2) 128 
Disaster relief (includes disaster assistance, disaster response)

Natural disaster: finding, managing and sharing people and information. Gregory, G.

31(2) 122

Post-earthquake co-ordination of technical resources: the need for a unified approach. Brunsdon, D.R.: Charleson, A.W.: King, A.B.: Middleton, D.A.: Sharpe, R.D.: Shephard, R.B.: Smith, E.G.C.

29(4) 280

The City of Los Angeles experience during the 1994 Northridge earthquake: managing resources and information. Quadri, N.D. 30(1) 2

\section{Discussion}

Discussion - the seismic resistance of unreinforced masonry cantilever walls in low seismicity areas, by N.T.K.Lam, J.L.Wilson and G.L. Hutchinson, 28(3) pp 179-195. Andrews, A.L.

29(1) 57

Earthquake damage (includes post-earthquake response, restoration, reconstruction): also see Reconnaissance reports

An analysis of the failure of the columns of a 600 metre length of the Hanshin elevated expressway during the Great Hanshin Earthquake of 17 January 1995. Park, R.

29(2) 73

Damage and intensities in the magnitude 7.81931 Hawke's Bay, New Zealand, earthquake. Dowrick, D.J.

31(3) 139

Earthquake insurance loss assessments for regions of Australia. Shephard, R.B.: Smith, E.G.C.: Spurr, D.D.

$$
30(1) 32
$$

Earthquake risk (prone) buildings - the Gisborne experience. Wells, J.D.

29(3) 147
Post-earthquake response: issues associated with compiling a register of engineers. Brunsdon, D.R.: Shephard, R.B.

31(4) 281

The 1855 Wairarapa, New Zealand, earthquake - analysis of historical data. Grapes, R.: Downes, G. (and see Errata).

30(4) 271

The City of Los Angeles experience during the 1994 Northridge earthquake: managing resources and information. Quadri, N.D.

$30(1) 2$

Vulnerability of different classes of low-rise buildings in the 1987 Edgecumbe, New Zealand, earthquake. Dowrick, D.J.: Rhoades, D.A. 30(3) 227

\section{Earthquake engineering}

A decade of progress - see below, Progress review.

Aspects of drift and ductility capacity of rectangular cantilever structural walls. Priestley, M.J.N.: Kowalsky, M.J.

31(2) 73

Brief comments on elastic flexibility of reinforced concrete frames and significance to seismic design. Priestley, M.J.N.

$31(4) 246$

Editorial. Moss, P.J.

29(3) Unpaged

Experimental results and dynamic parameters for the Penguin Vibration Damper (PVD) for wind and earthquake loading. Monti, M.D.: Zhao, J.X.: Gannon, C.R.: Robinson, W.H.

31(3) 177

Geotechnical earthquake engineering in New Zealand summary of ongoing research. McManus, K.J.

29(2) 128

NZNSEE President's page. King, A.B

$30(2) 113$

Progress review. Earthquake Engineering in the decade since the Edgecumbe earthquake. A decade of progress in seismology since the Edgecumbe earthquake. Smith, E.G.C.

30(2) 163

A decade of progress since the Edgecumbe earthquake buildings. Jury, M.D

30(2) 174

A decade of progress since the Edgecumbe earthquake: risk and insurance. hephard, R.B.

30(2) 185 
Developments in seismic design procedures for bridges in New Zealand. Park, R.

30(2) 177

Lifelines engineering - a long way in a decade. Brunsdon, D.R 30(2) 194

NZNSEE 1997 Conference feature session on last decade report by session chairman. Hopkins, D.C.

Recent developments in earthquake geotechnical engineering. Pender, M.J. 30(2) 167

The estimation of structural modal parameters from the responses of the Gisborne Post Office building in recent earthquakes. Zhao, J.X.

31(1) 51

The seismic behaviour of small reinforced concrete beamcolumn knee joints. Megget, L.M.

$31(4) 215$

An analysis of the failure of the columns of a 600 metre length of the Hanshin elevated expressway during the Great Hanshin Earthquake of 17 January 1995. Park, R.

29(2) 73

Earthquake design and performance of steel structures. Krawinkler, $\mathrm{H}$.

Energy dissipation and liquefaction at Port Island, Kobe. Davis,

$$
\text { R.O.: Berrill, J.B. 31(1) } 33
$$

Lessons for New Zealand lifelines organisations from the 17 January 1995 Great Hanshin Earthquake. Brunsdon, D.R.: Britton, N.R.: Carter, R.J.: Crimp, R.F.: Gates, E.F.: Gordon, M.A.: Hughson, G.J.: Lamb, A.J.W.: Leslie, P.D.: Wabnitz, G.: Watson, A.C. 29(1) 1

Preliminary paleoearthquake investigations of active faults on Awaji Island, Japan, in relation to the 1995 Great Hanshin (Kobe) Earthquake. Van Dissen, R.: Begg, J.: Awata, Y.

The City of Los Angeles experience during the 1994 Northridge earthquake: managing resources and information. Quadri, N.D.

$30(1) 2$

World earthquakes of magnitude 6.0 and greater

- August 1997 to October 1997.

30(4) 372

- November 1997 to January 1998.

31(1) 68

- February 1998 to April 1998.

31(2) 135
- May 1998 to July 1998.

31(3) 211

- August 1998 to October 1998.

31(4) 297

\section{Earthquakes in New Zealand}

A note on the Hanmer Springs earthquake, Thursday 29/08/1996. Berrill, J.B.

29(3) 208

Attenuation of peak ground accelerations in New Zealand earthquakes. Zhao, J.X.: Dowrick, D.J.: McVerry, G.H.

$30(2) 133$

Damage and intensities in the magnitude 7.81931 Hawke's Bay, New Zealand, earthquake. Dowrick, D.J.

31(3) 139

Magnitudes of New Zealand earthquakes, 1901-1993. Dowrick, D.J.: Rhoades, D.A.

Principal earthquakes in New Zealand in 1995. Webb, T.H. 29(1) 56

Principal earthquakes in New Zealand in 1996. Webb, T.H.

30(1) 1

Significant New Zealand earthquakes

- August 1997 to October 1997.

30(4) 371

- November 1997 to January 1998.

- February 1998 to April 1998.

$31(2) 136$

- May 1998 to July 1998.

- August 1998 to October 1998.

31(4) 298

The 1855 Wairarapa, New Zealand, earthquake - analysis of historical data. Grapes, R.: Downes, G. (And see Errata, 31(1) p.64)

30(4) 271
Lessons for New Zealand lifelines organisations from the 17 January 1995 Great Hanshin Earthquake. Brunsdon, D.R.: Britton, N.R.: Carter, R.J.: Crimp, R.F.: Gates, E.F.: Gordon, M.A.: Hughson, G.J.: Lamb, A.J.W.: Leslie, P.D.: Wabnitz, G.: Watson, A.C. 29(1) 1 
Natural disaster: finding, managing and sharing people and information. Gregory, G.

31(2) 122

Post-earthquake building safety evaluation procedures Preparedness checklist and response plan for territorial authorities. NZNSEE Study Group on postearthquake building safety evaluation procedures.

Post-earthquake response: issues associated with compiling a register of engineers. Brunsdon, D.R.: Shephard, R.B.

31(4) 281

Earthquake prediction (includes earthquake warning systems)

Editorial. Moss, P.J.

29(1) Unpaged

Editorial. Moss, P.J.

29(1) Unpaged

Operational requirements for an earthquake forecasting programme for New Zealand. Vere---Jones, D.: Harte, D.: Kozuch, M.J.

31(3) 194

Editorial. Moss, P.J

29(3) Unpaged

Editorial. Moss, P.J.

29(4) Unpaged

Earthquake risk buildings (and see refurbishment and retrofitting)

NZNSEE President's page. King, A.B.

$30(2) 113$

\section{Errata}

Case study: Christchurch Government Buildings strengthening and refurbishment. Hare, H.J.

29(3) 141

Displacement-based seismic assessment of existing reinforced concrete buildings. Priestley, M.J.N. 29(4) 256

Earthquake risk (prone) buildings - the Gisborne experience. Wells, J.D.

29(3) 147

Letter - re Earthquake risk (prone) buildings - the Gisborne experience, by J.D.Wells, 29(3), September 1996. Brunsdon, D.R.

29(4) 285

The strengthening of Auckland Town Hall. Robertson, T.W.

29(4) 273
Twenty-five year index Volume 1 (1968) to Volume 25 (1992). (And see Errata, 31(4) p. 195.)

30(1) 65 
Preliminary paleoearthquake investigations of active faults on Awaji Island, Japan, in relation to the 1995 Great Hanshin (Kobe) Earthquake. Van Dissen, R.: Begg, J.: Awata, Y.

29(3) 172

The dynamic properties of a pumiceous sand. Marks, S.: Larkin, T.J.: Pender, M.J.

31(2) 86

\section{Geomechanics/Geotechnical engineering}

Earthquake resistant design of foundations. Pender, M.J.

Geotechnical earthquake engineering in New Zealand summary of ongoing research. McManus, K.J.

29(2) 128

Recent developments in earthquake geotechnical engineering. Pender, M.J.

US-Japan workshop on geotechnical aspects of recent earthquakes. McManus, K.J.

29(2) 124

Energy dissipation and liquefaction at Port Island, Kobe. Davis, R.O.: Berrill, J.B

$31(1) 33$

Liquefaction susceptibility based on dissipated energy: a consistent design methodology. Davis, R.O.: Berrill, J.B.

29(2) 83

Observation and synthesis of spatially-incoherent weak-motion wavefields at Alfredton basin, New Zealand. Haines, A.J.: Yu, J.

$30(1) 14$

Recent developments in earthquake geotechnical engineering. Pender, M.J.

$30(2) 167$

The Tikokino earthquake of 11 April 1993: movement at the plate interface in southern Hawkes Bay. Reyners, M.: McGinty, P.: Ansell, J.: Ferris, B.

$30(3) 242$
US-Japan workshop on geotechnical aspects of recent earthquakes. McManus, K.J.

29(2) 124

\section{Insurance}

A decade of progress since the Edgecumbe earthquake: risk and insurance. Shephard, R.B. (And see Earthquake engineering.)

$30(2) 185$

Counting the cost: the economic effects of a major earthquake. Gregory, G.

31(4) 288

Earthquake insurance loss assessments for regions of Australia. Shephard, R.B.: Smith, E.G.C.: Spurr, D.D.

30(1) 32

Operational requirements for an earthquake forecasting programme for New Zealand. Vere-Jones, D.: Harte, D.: Kozuch, M.J. 31(3) 194

Prediction of insurance loss from earthquakes. Walker, G.R.

$30(1) 40$

\section{Lifelines}

Damage and intensities in the magnitude 7.81931 Hawke's Bay, New Zealand, earthquake. Dowrick, D.J.

31(3) 139

Lessons for New Zealand lifelines organisations from the 17 January 1995 Great Hanshin Earthquake. Brunsdon, D.R.: Britton, N.R.: Carter, R.J.: Crimp, R.F.: Gates, E.F.: Gordon, M.A.: Hughson, G.J.: Lamb, A.J.W.: Leslie, P.D.: Wabnitz, G.: Watson, A.C. 29(1) 1

Lifelines engineering - a long way in a decade. Brunsdon, D.R. 30(2) 194

US-Japan workshop on geotechnical aspects of recent earthquakes. McManus, K.J. 29(2) 124 
The seismic behaviour of small reinforced concrete beamcolumn knee joints. Megget, L.M.

31(4) 215

\section{Seismic design}

A decade of progress since the Edgecumbe earthquake buildings. Jury, M.D. (And see Earthquake engineering.)

$30(2) 174$

A review of code provisions for torsional seismic effects in buildings. Paulay, $\mathrm{T}$.

30(3) 252

Aspects of drift and ductility capacity of rectangular cantilever structural walls. Priestley, M.J.N.: Kowalsky, M.J.

Book reviews.

29(1) 59

Brief comments on elastic flexibility of reinforced concrete frames and significance to seismic design. Priestley, M.J.N.

31(4) 246

Developments in seismic design procedures for bridges in New Zealand. Park, R.

30(2) 177

Discussion - The seismic resistance of unreinforced masonry cantilever walls in low seismicity areas, by N.T.K. Lam, J.L. Wilson and G.L. Hutchinson, 28(3) pp 179-195. Andrews, A.L.

$$
\text { 29(1) } 57
$$

Earthquake design and performance of steel structures. Krawinkler, $\mathrm{H}$.

29(4) 229

Earthquake resistant design of foundations. Pender, M.J.

29(3) 155

Liquefaction susceptibility based on dissipated energy: a consistent design methodology. Davis, R.O.: Berrill, J.B.

29(2) 83

Recent developments in earthquake hazard mitigation in the United States. Holmes, W.T.

29(2) 107

Seismic design for torsional response of ductile buildings. Paulay, $\mathrm{T}$.

29(3) 178

Seismic design within architectural education. Charleson, A.W.

$30(1) 46$
Seismic load tests on two concrete interior beam-column joints reinforced by plain round bars designed to pre-1970s codes. Liu, A.: Park, R.

31(3) 164

Seismic response of bridge knee joints having columns with interlocking spirals. Ingham, J.M.: Priestley, M.J.N. Seible, F.

$30(2) 114$

The fundamentals of an earthquake standard. King, A.B.

29(3) 199

The seismic behaviour of small reinforced concrete beamcolumn knee joints. Megget, L.M. 31(4) 215

The strengthening of Auckland Town Hall. Robertson, T.W

29(4) 273

Unreinforced masonry structures - an Australian overview. Page, A.W.

29(4) 242

Seismic hazards (includes Seismic risk, Seismic zoning)

Displacement-based seismic assessment of existing reinforced concrete buildings. Priestley, M.J.N. 29(4) 256

Earthquake hazard in Christchurch. Dowrick, D.J.: Berryman, K.R.: McVerry, G.H.: Zhao, J.X. 31(1) 1

Earthquake insurance loss assessments for regions of Australia. Shephard, R.B.: Smith, E.G.C.: Spurr, D.D.

$30(1) 32$

Intraplate seismicity and zonation. Bolt, B.A.

29(4) 221

Prediction of insurance loss from earthquakes. Walker, G.R.

$30(1) 40$

Recent developments in earthquake hazard mitigation in the United States. Holmes, W.T.

29(2) 107

Vulnerability of different classes of low-rise buildings in the 1987 Edgecumbe, New Zealand, earthquake. Dowrick, D.J.: Rhoades, D.A. $30(3) 227$ 
Workshop on seismic hazard mitigation of non-engineered structures National Geophysics Research Institute Hyderabad, India 2-8 June 1996.

29(3) 209

Seismology (includes Strong motion seismology)

A decade of progress in seismology since the Edgecumbe earthquake. Smith, E.G.C. (And see Earthquake ngineering.)

30(2) 163

Attenuation of peak ground accelerations in New Zealand earthquakes. Zhao, J.X.: Dowrick, D.J.: McVerry, G.H.

$30(2) 133$

Damage and intensities in the magnitude 7.81931 Hawke's Bay, New Zealand, earthquake. Dowrick, D.J.

31(3) 139

Evidence for temporal clustering of large earthquakes in the Wellington region from computer models of seismicity. Robinson, R.: Benites, R.: Van Dissen, R.

31(1) 24

Intraplate seismicity and zonation. Bolt, B.A.

29(4) 221

Magnitudes of New Zealand earthquakes, 1901-1993. Dowrick, D.J.: Rhoades, D.A. 31(4) 260

Observation and synthesis of spatially-incoherent weak-motion wavefields at Alfredton basin, New Zealand. Haines, A.J.: Yu, J.

30(1) 14

Principal earthquakes in New Zealand in 1996. Webb, T.H.

$30(1) \quad 1$
Principal earthquakes in New Zealand in 1995. Webb, T.H.

29(1) 56

A decade of progress since the Edgecumbe earthquake buildings. Jury, M.D. (And see Earthquake engineering.)

30(2) 174

A review of code provisions for torsional seismic effects in buildings. Paulay, $\mathrm{T}$.

$30(3) 252$

Earthquake risk (prone) buildings - the Gisborne experience. Wells, J.D.

29(3) 147

Liquefaction susceptibility based on dissipated energy: a consistent design methodology. Davis, R.O.: Berrill, J.B.

29(2) 83

Seismic load tests on two concrete interior beam-column joints reinforced by plain round bars designed to pre-1970s codes. Liu, A.: Park, R.

31(3) 164

The fundamentals of an earthquake standard. King, A.B.

29(3) 199

Unreinforced masonry structures - an Australian overview. Page, A.W.

29(4) 242

\section{Volcanoes}

The estimation of structural modal parameters from the responses of the Gisborne Post Office building in recent earthquakes. Zhao, J.X. 31 (1) 51

The modified Mercalli earthquake intensity scale - revisions arising from recent studies of New Zealand earthquakes. Dowrick, D.J. 29(2) 92

The Tikokino earthquake of 11 April 1993: movement at the plate interface in southern Hawkes Bay. Reyners, M.: McGinty, P.: Ansell, J.: Ferris, B. $\quad 30(3) 242$ 